\title{
UNTYING EMPIRICAL KNOTS: DETERIORATION OF PROFITABILITY, ECONOMIC FAILURE, AND FINANCIAL INSOLVENCY IN THE PHILIPPINES BEFORE COVID-19 OUTBREAK
}

\author{
Emmanuel A. Onsay \\ Faculty, Accountancy \& Economics Department, Partido State University, the \\ Philippines \\ School of Economics, De La Salle University, the Philippines \\ (emmanuel.onsay@parsu.edu.ph) \\ DOI: https://doi.org/10.22452/jati.vol26no1.2
}

\begin{abstract}
Corporate bankruptcy has enormous economic ramifications, particularly for investors and creditors of publicly listed companies (PLC). Prior to a corporate collapse, a company's financial status is frequently in jeopardy, and its performance either affirms progress or predicts failure. As a result, management is interested in a technique of determining a company's financial distress. Financial accounting analyses were performed to determine the solvency, liquidity, profitability, and gearing capacity of 136 firms, with 680 economic entries, before CoVid-19 Outbreak. To scrutinise financial distress, the Altman Z-scores and financial zone of discriminations were generated through GB bankruptcy, and PLC bankruptcy model. The link between declining profitability, economic failure, and financial insolvency as indicators of financial distress was examined through panel regression with random factors. Prior to the COVID-19 outbreak, there were no signs of declining profitability, economic collapse, or financial insolvency in the Philippines, according to the findings of the study. Individual components of financial distress and the overall z-score have no statistically meaningful association with financial performance and position markers. As a result, the solvency ratio has little predictive value in forecasting financial distress. The fact that a company has a higher solvency ratio does not also imply that it is less likely to go bankrupt. The findings go counter to classic accounting perspectives and pure managerial research that claim the solvency ratio is always a reliable predictor of financial distress. Finally, the paper examined the financial health of firms and untangled the knots of financial distress.
\end{abstract}

Keywords: financial analysis, financial distress, Altman Z-score of bankruptcy, panel econometrics, publicly-listed companies 


\section{Introduction}

There have been several instances of business blunders during the last few years. As a result, many enterprises are in financial difficulties or have gone bankrupt. A troubling tendency is emerging as a result of numerous occurrences of similar errors in many sectors around the world. According to Pauli and Wolf (2017) and Sicat (2017), Hanjin Philippines, the largest foreign investor in the Subic Bay Freeport Region, has become financially challenged due to its huge debt (2010). The corporation can no longer continue its operations due to a lagging revenue and debt burden. This is just one of several examples in the Philippines that have been documented.

Financial distress is when a firm is having financial problems, and if these problems are not resolved, the company may go bankrupt. A Financial crisis, according to Brigham and Daves (2007), arises when cash flow projections indicate that the company will soon be unable to satisfy its obligations. Companies might benefit from a better understanding of the causes that contribute to financial difficulties in order to take preventative measures to avoid bankruptcy. Based on a solvency ratio of 67 percent, a study by Brîndescu-Olariu (2016a) encompassing 1176 Romanian enterprises revealed general categorisation accuracy. Although this degree of precision leaves a lot of space for error, it is indeed enough to be employed as a solvency ratio classifier (Chung et al., 2008). Because the tests were conducted on a paired sample of 588 bankrupt enterprises and 588 non-bankrupt enterprises, the optimum cut-off value was not deemed appropriate for the entire population (which has an annual bankruptcy rate of less than 3 percent), therefore no assessment technique was designed.

In this study, financial statements of publicly traded companies on the Philippine Stock Exchange were utilised for meticulous and cross-sectional accounting investigation. The goal of the study was to test if solvency analysis could be used as a predictor of a company's financial problems and untie the knots of relationships between the elements of financial distress (deterioration of profitability, economic failure and financial insolvency) and indicators of financial position and performance (solvency, liquidity, profitability, and growth). The Altman technique, a novel financial tool of interpreting financial bankruptcy, was performed and the Z-scores were generated by manipulating financial statements. The Altman Z-score is a tedious procedure of analysing bankruptcy and is proven to be nearly accurate in evaluating the financial distress of companies (Russ, Peffley, \& Greenfield, 2004). It would seem logical to foresee the risk of financial trouble in order to avert future bankruptcy for businesses and stakeholders, particularly investors, lenders, and capital market participants. According to Chouhan, Chandra, and Goswami (2014), severe financial difficulty poses a threat 
to long-term viability. Therefore, setting up an early warning mechanism for corporate financial problems can help improve the economic sustainability of businesses.

\section{Review of Related Literature}

\section{Financial analyses and financial distress}

Solvency refers to a company's ability to meet medium and long-term obligations, particularly with its own funds. This entails a better match between long-term financing needs for tangible and intangible economic assets and continuous financing resources, such as equity and long-term debt (Petrescu, 2008). Solvency evaluation is complicated and can be done from a variety of perspectives. Financial ratios, such as solvency, liquidity, growth, and profitability (If nescu, 1999), (Stancu, 2007), (Balte, 2010), (Bistriceanu, 2001), (Eros-Stark, 2001), (Petrescu, 2009), (Petrescu, 2008) are used in national \& international accounting parlance and economic practice. Previous research (Brîndescu-Olariu 2015 \& 2014) has shown that the autonomy ratio, debt ratio, equity working capital, and labor productivity of Romanian enterprises can be used to assess bankruptcy risk. In relation to the aforementioned model, the purpose of this study is to determine whether the solvency ratio is valid as a predictor of bankruptcy and whether the Romanian model is admissible in the Philippine context.

According to Brigham and Daves (2007), financial distress begins when cash flow projections show that the company will soon be unable to meet its obligations. Understanding the scenario of the company's financial difficulties is expected to lead towards actions that may anticipate events, which drive bankruptcy. It is very critical to identify the predictors of financial distress, but it's also essential to develop a statistical model that can accurately forecast distress. One of the most well-known models for predicting financial difficulty is the Altman's Z-score (Altman, 1968). Despite the various models for predicting financial distress that are available in the research, the economic literature more typically uses Z-score and O-score models (Adnan Aziz, \& Dar, 2006). Over the distinct phases, Altman examined distressed businesses from 1969-1975, 1976-1995 and 1997-1998 using Z-score model. Based on data from one economic reporting period prior to bankruptcy, the proof showed that Z-score precision ranged from $80 \%$ to $90 \%$ in the repeated cases.

A prior study (Brîndescu-Olariu, 2016a) looked at the solvency ratio's ability to predict company bankruptcy. Based on a solvency proportion of 67 percent, this study found that a combined sample of 1176 Romanian enterprises had a general precision of categorisation. Despite the fact that this degree of precision allows a lot of room for error, it is thought to be sufficient for creating a 
useful solvency ratio classifier (Chung et al., 2008). In 2008, Patrick Enyi's research employed the comparative solvency ratio (RSR) as one of the models for predicting financial trouble (Envi, 2008). Recent studies have also shown that the comparative solvency ratio can be effectively used in the measurement of bank liquidity for efficient bank and financial services administration.

\section{Theoretical Framework}

When a business is in financial difficulties, it frequently passes through all of the stages of downturn.

\section{Deterioration of Profitability}

Sales declines, changes in operating income, and negative stock returns are all indicators of profitability deterioration. According to Whitaker (1999), operational income drops to 46.32 percent below the sector average in the early stages of financial distress. The company exhibits significant operational inefficiencies, missed operational objectives, and associated profit margins at this phase. Deterioration of profitability refers to a drop in performance as a result of the scheme's degradation processes (Outecheva, 2007)

Although the company is still solvent, management may take steps to improve the fluctuating profitability. The operations, on the other hand, frequently fail. The failure of these actions is frequently caused by inertia and hyperactivity. In the various waves of management responses to economic challenges, inertia and hyperactivity are frequently mentioned. First, the company's response to negative procedures is delayed. As previously said, if a negative consequence can be detected, it usually indicates the need to behave. This inertia is quite costly to the company's efficiency. The leadership then overreacts, often with unnecessary risks, in order to break the downward trend. A synergistic effect promotes the fall in value since various negative procedures communicate in financial distress. As a result of the managerial activities taken, the momentary gain in the firm's worth does not compensate for the negative effects accumulated in working operations and financial distress due to the company's degradation in performance leading to failure.

\section{Economic Failure}

According to financial requirements, Altman and Hotchkiss (2005) define failure as a situation in which "the realized rate of return on invested capital, with risk consideration allowance, is significantly and persistently lower than the prevailing rate on comparable investments". Failure depicts the company's descent from a viable to a marginal, "acceptable" state. As a result of the operating reduction, the 
money buffer is becoming increasingly thin. A short cash age triggers a transition in the company's economic state from solvent to distress as a result of a continuous drop in cash flow (Outecheva, 2007).

\section{Financial Insolvency}

The failure stage of the distress cycle is more severe than the preceding phases due to the interaction of declining profitability and insufficient liquidity. The most serious problem a corporation faces at this point is a lack of cash flows generated by operating activity. Stocks and flows are two important aspects of the bankruptcy problem, according to Ross et al. (2002). When operating cash flows are insufficient to satisfy financial debt, insolvency based on flow occurs. This is a situation in which an organisation is unable to raise sufficient funds to meet its obligations or pay its debts as they become due. (Outecheva, 2007).

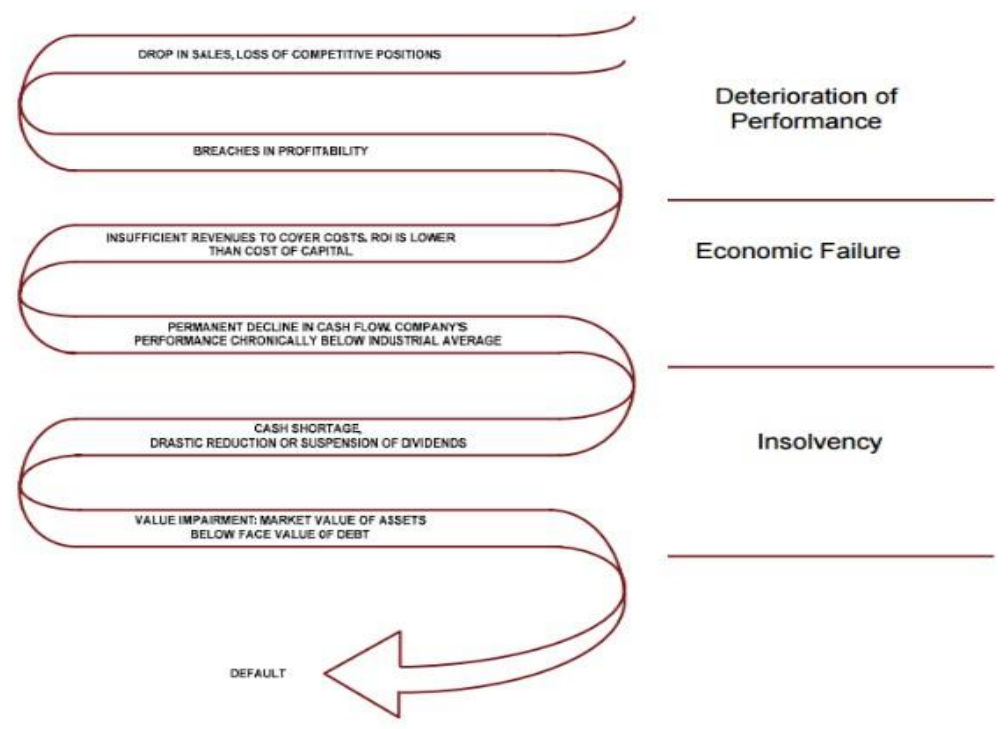

Figure 1: The downward spiral framework of financial distress (Outecheva, 2007) 
The illustration herein below gives a general research flow.

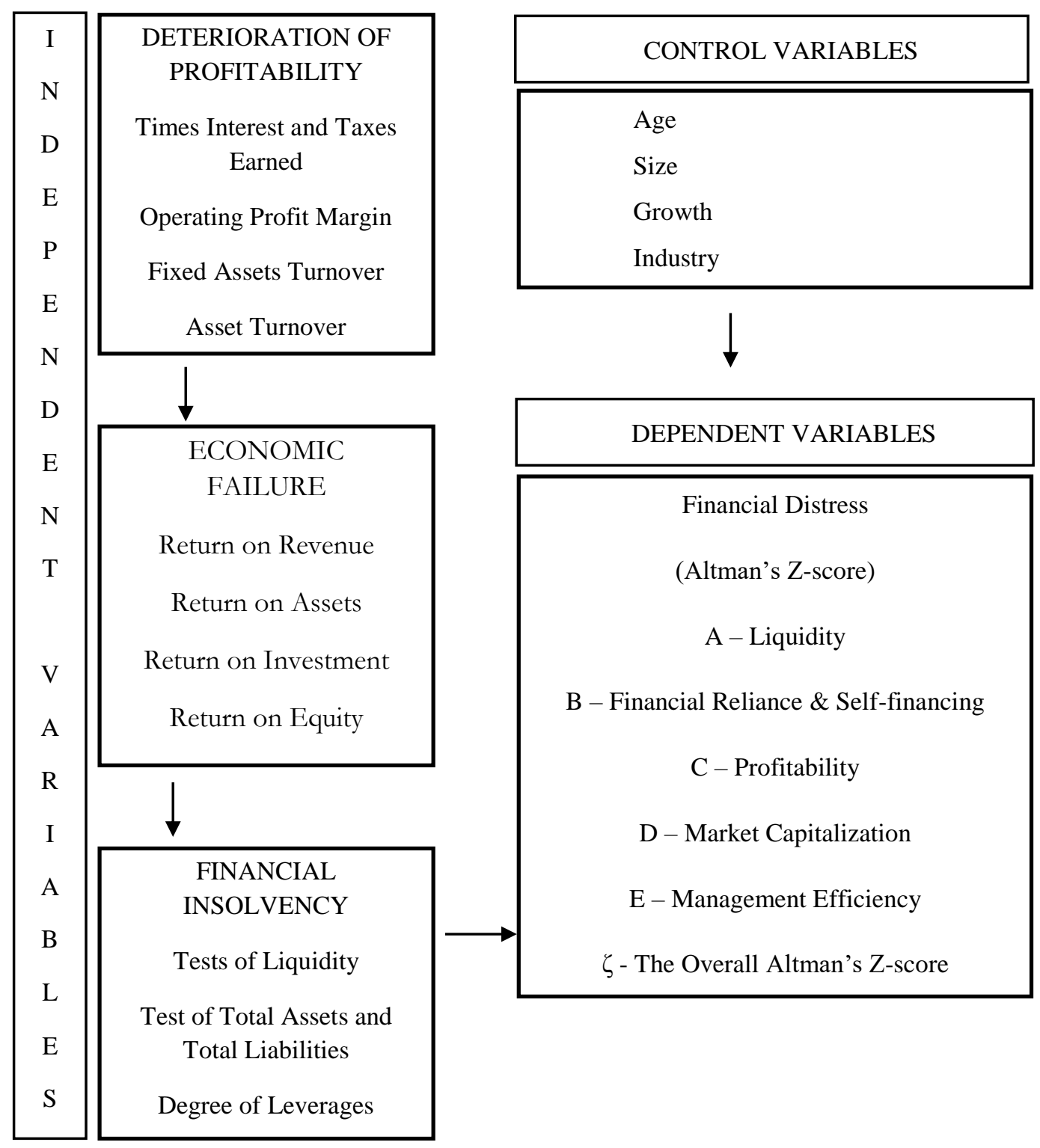

Figure 2: Researcher's theoretical framework

\section{Research Methodology}

The research design used in the research is the combination of descriptivecorrelation and causal-explanatory. 


\section{Data and Variables}

The sample is taken from the publicly listed businesses between 2013 and 2017 on the Philippines Stock Exchange. A total of 680 observations were taken for the sample ranging from the companies' solvency, liquidity, and profitability to macroeconomic variables, such as firm age, size, growth, and type of industry as control variables.

\section{The Altman Z-Score of Bankruptcy}

The Altman Z-score model was used to forecast the business' financial distress - A model for estimating the likelihood of bankruptcy. This methodology can be used to predict the probability of a financially distressed company declaring bankruptcy within a given time frame (Altman, 1968).

In this study, the Altman Z-score was constructed as follows:

\section{A - Liquidity}

ALTMANX1 = Working Capital/Total Assets

After subtracting current liabilities, working capital is the remaining current asset. It is essentially the difference between a publicly traded company's current assets and current liabilities. This is a liquidity indicator that represents the short-term financial health of a company. A firm with positive working capital has the ability to settle its short-term maturing commitments and produce funds for investment from its operating activities. On the other hand, negative working capital indicates that a company's present assets are insufficient, and it may struggle to meet shortterm obligations.

\section{B - Financial Reliance $\mathcal{E}$ Self-financing}

ALTMANX2 = Retained Earnings/Total Assets

A high retained earnings to total assets ratio, means that it has sufficient fund to finance itself. As a result, it has adequate equity financing for capital expenditure. It also reflects company's previous degree of profitability and depicts financial reliance. The company will not depend on borrowings if the ratio of retained earnings to total asset is high. However, if the firm's ratio is low, it asserts that the publicly listed companies is not self-reliant and cannot finance its capital 
expenditure by its own fund. Instead, the company will be relying on borrowings. Thus, it heightens the probability of a firm going bankrupt.

\section{C-Profitability}

\section{ALTMANX3 $=$ EBIT/Total Assets}

Earnings Before Interest and Taxes (EBIT) is a metric for determining a company's profitability. It refers to a company's ability to derive profits from its operations. When using the "going concern" as an underlying accounting assumption, the EBIT/Total Assets ratio demonstrates the firm's potential to earn enough revenue to sustain operations, meet currently maturing obligations, and extend growth.

\section{D-Market Capitalisation}

\section{ALTMANX4 $=$ Net Worth/Total Liabilities}

Net Worth is a measure of market capitalisation. It can be obtained by multiplying the number of outstanding shares by the current price of shares. The ratio shows the degree to which a company's market value would decline when it declares bankruptcy before the value of liabilities exceeds the value of assets in the statement of financial position. A high ratio indicates high confidence of investors to trust the company's financial strength.

\section{E-Management Efficiency}

\section{ALTMANX5 $=$ Sales $/$ Total Assets}

The Sales to Total Assets ratio indicates company's efficiency. It shows how efficiently the management utilises assets to generate revenues despite competitive market. A high ratio could be translated that the management requires a small investment to generate sales, which increases the overall profitability of a firm. On the other hand, a low or falling ratio means that the firm will need to use more economic resources to generate enough sales, which will decrease the company's profitability.

\section{$\zeta$ - The Overall Altman's Z-score}

The ATLMAN Z-Score represents the summation of the five key Altman Ratios. The ALTMAN X1, X2, X3, X4 and X5 reflects liquidity, firm age, profitability, financial structure and capital turnover, respectively. The Altman Z-Score $(\zeta)$ is generated as follows: 


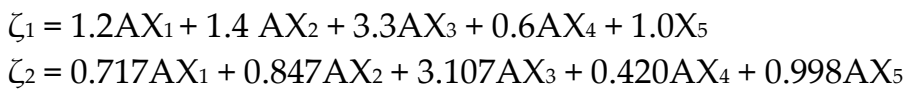

Where:

Zeta $\left(\zeta_{1}\right)=$ Altman's Z-score Model 1 General Model

Zeta $\left(\zeta_{2}\right)=$ Altman's Z-score Model 2 Manufacturers and Publicly-listed Companies

$\mathrm{X}_{1}$ is the Working Capital/Total Assets ratio

$\mathrm{X}_{2}$ is the Retained Earnings/Total Assets ratio

$\mathrm{X}_{3}$ is the Earnings before settlement of Interest and Tax/Total Assets ratio

$\mathrm{X}_{4}$ is the Market Value of Net Worth and Capitalisation/Total Liabilities ratio

$\mathrm{X}_{5}$ is the Total Sales/Total Assets ratio

The Z-Score described above is a linear combination of five accounting ratios that are weighted by coefficients that are constant across three industry classifications. The coefficients were calculated using a combination of estimation and painstaking manipulation of historical accounting data.

\section{Interpretation of Z-Score}

The Zone of Discrimination is a numerical clustering of Z-score ranges used to evaluate companies' financial distress, neutrality, and financial stability.

Zone of Discrimination $\zeta_{1}$

\begin{tabular}{|l|l|l|l|l|l|l|}
\hline & ZONE OF DISTRESS & & GREY ZONE & & ZONE OF STABILITY & \\
\hline 0 & & 1.8 & & 3.0 & & 4.0 \\
\hline
\end{tabular}

1. If Z-Score is less than 1.8, it suggests high chances of bankruptcy;

2. If Z-Score is between 1.8 and 3.0, it suggests that the firm is in gray or ambiguous area, and firms have moderate chance of filing for bankruptcy; and 3. If Z-Score is more than 3.0, it implies low chances or no chance of bankruptcy.

Zone of Discrimination $\zeta_{2}$

\begin{tabular}{|c|c|c|c|c|c|c|}
\hline & $\begin{array}{c}\text { ZONE OF } \\
\text { DISTRESS }\end{array}$ & & GREY ZONE & & $\begin{array}{c}\text { ZONE OF } \\
\text { STABILITY }\end{array}$ & \\
\hline 0 & & 1.20 & & 2.90 & & 4.0 \\
\hline
\end{tabular}

1. If $Z$-Score is less than 1.20, it suggests high chances of bankruptcy;

2. If Z-Score is between 1.2 and 2.9, it suggests that the firm is in gray or ambiguous area, and firms have moderate chance of filing for bankruptcy; and 3. If Z-Score is more than 2.90, it implies low chances or no chance of bankruptcy 


\section{Financial Accounting Analytical tools}

To facilitate financial health examination, financial accounting ratios were generated and are analysed.

\section{i. Solvency Ratio}

The Total Debt-to-Equity Ratio was used to assess the amount of total incurred by the firm in relation to its equity.

Formula:

$S_{R}=$ Total Debt to Total Asset $=$ Total Asset $/$ Total Liability

Where:

$\mathrm{S}_{\mathrm{R}}=$ Solvency Ratio

\section{ii. Liquidity Ratio}

This ratio was used to determine the ability of the company to meet currently maturing obligations.

Formula:

$\mathrm{LR}=$ Current Assets/Current Liabilities

Where:

$\mathrm{LR}_{\mathrm{R}}=$ Liquidity Ratio

\section{iii. Profitability Ratios}

It measures the ability of the company to generate profits solely from its regular course of activities.

Formula:

$\mathrm{F}_{\mathrm{ATO}}=$ Revenue/Non-Current Assets

Ато $=$ Revenue $/$ Total Assets

$\mathrm{T}_{\mathrm{i}}=$ Earnings before Interest and Taxes/Interest and Taxes

$\mathrm{O}_{\mathrm{m}}=$ Earnings before Interest and Tax/Revenue

ROR $=$ Net Income/Revenue

ROA $=$ Net Income/Total Assets

ROI $=$ Return On Revenue*Asset Turn Over

ROE $=$ Net Income/Net Worth 
Where:

$\mathrm{F}_{\text {ATO }}=$ Fixed Assets Turn Over

Ато $=$ Asset Turn Over

$\mathrm{T}_{\mathrm{i}}=$ Times Interest and Taxes Earned

$\mathrm{O}_{\mathrm{m}}=$ Operating Profit Margin

ROR $=$ Return on Revenue

ROA $=$ Return On Assets

ROI $=$ Return On Investment

ROE $=$ Return On Equity

\section{iv. Inter-financial Accounting Ratios}

These set of ratios were used to derive the figures utilised for solvency, liquidity, profitability, and gearing capacity.

Formula:

La $=$ Total Liabilities/Total Assets

Le $=$ Total Liabilities/Total Equity

Int $\mathrm{T}=$ Earnings before Interest and Tax - Net Income

Tce $=$ Net Income + Interest and Taxes - Revenue

$\operatorname{CosEx}=$ Revenue - Interest and Taxes - Net Income

$\mathrm{DR}=$ Total Liabilities/Economic Resources

$\mathrm{ER}=$ Total Equity/Economic Resources

$\mathrm{EM}=1 /$ Equity Ratio

RORA = Return On Assets*Equity Multiplier

FLI = Return On Equity/Return On Assets

FATLL $=$ Noncurrent Assets /Non-Current Liability

FATE $=$ Non-Current Assets/Total Equity

RORCA $=$ Net Income/Current Assets

$\mathrm{GR}=(\text { Net Income/Revenue })^{*} 100$

NCA $=$ Total Assets - Current Assets

NCL $=$ Total Liabilities - Current Liabilities

Where:

La $=$ Leverage of Asset

Le $=$ Leverage of Equity

Int $\mathrm{T}=$ Interest and Taxes

Tce $=$ Total Cost and Expenses

CosEx $=$ Cost and Expenses

$\mathrm{DR}=$ Debt Ratio

$E R=$ Equity Ratio

$\mathrm{EM}=$ Equity Multiplier 
RORA $=$ Return on Residual Assets

FLI $=$ Financial Leverage Index

FATLL $=$ Fixed Assets to Long Term Liabilities

FATE $=$ Fixed Assets to Total Equity

RORCA $=$ Rate of Return on Current Assets

$\mathrm{GR}=$ Growth Ratio

NCA $=$ Non-Current Assets

NCL $=$ Non-Current Liability

\section{Empirical Procedure}

The researchers employed the panel regression model and causality analyses to examine solvency as a predictor of financial distress. In a Random-effects model, variation between entities is believed to be random and unrelated to the predictor or independent variables in the model (Greene, 2002). The main distinction between fixed and random is whether the unobserved individual effect has elements that are correlated with the model's regressors, not whether the effects are stochastic or not. The researcher believes that differences in publicly traded company data have an impact on the dependent variable. Because the entity's error term is not linked with the predictors, time-invariant variables can be used as explanatory variables in random effects models. As a result, these models were used to analyse data from a panel. Individual traits that may or may not influence the predictor variables must be specified in random-effect models. Because some variables may not be available, omitted variable bias in the model could become a problem (Torres-Reyna, 2007). Furthermore, the random effect allows inferences to be generalised beyond the sample size utilised in the model. The researcher employed the Hausman test to determine if the effects were fixed or random. The null hypothesis is that the unique errors $\left(u_{i}\right)$ are not linked with the regressors; the alternative hypothesis is that they are (Greene, 2002). The researcher created a fixed and random effects model, recorded the results, and then executed the test. Prob>chi2 is more than 0.05, according to the Hausman test. As a result, the researcher used random effects. This study utilised STATA, R-Studio, and GNU Regression, Econometrics and Time-Series Library Applications (Gretl) to processed and examine the panel data.

\section{Econometric Model}

The econometric models were estimated and constructed based on financial accounting theories as follows:

$$
y=\beta 0+\beta 1 x+\sum_{k=1}^{k} \delta_{k} z_{k}
$$


where $\mathrm{y}=$ Financial distress measured through Altman Z-scores of Bankruptcy, $\mathrm{x}$ represents financial position and performance indicators, and $z_{k}$ captures all other control variables. The matching of dependent and independent variables, and the list of variables involved are shown in Tables 1 and 2 in this section.

Model 1

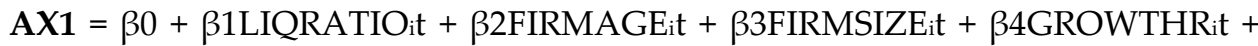
$\beta 5$ TYINDSTRY $Y_{i t}+\alpha_{i}+\varepsilon_{i t}$

Model 2

$\mathbf{A X 2}=\beta 0+\beta 1$ TINTTAXE $_{\mathrm{i}} \mathrm{t}+\beta 2$ FIRMAGE $_{\mathrm{i}} \mathrm{t}+\beta 3$ FIRMSIZE $_{\mathrm{i}} \mathrm{t}+\beta 4$ GROWTHR $_{\mathrm{i}} \mathrm{t}+$ $\beta 5$ TYINDSTRY ${ }_{\mathrm{i}} \mathrm{t}+\alpha_{\mathrm{i}}+\varepsilon_{\mathrm{i}} \mathrm{t}$

Model 3

$\mathbf{A X 3}=\beta 0+\beta 1$ OPM $_{\mathrm{i}} \mathrm{t}+\beta 2$ LROR $_{\mathrm{i}} \mathrm{t}+\beta 3$ ROI $_{\mathrm{i}} \mathrm{t}+\beta 4$ FIRMAGE $_{\mathrm{i}} \mathrm{t}+\beta$ FIRMSIZE $_{\mathrm{i}} \mathrm{t}+$ $\beta 6$ GROWTHR $_{\mathrm{i}} \mathrm{t}+\beta$ TTYINDSTRY $_{\mathrm{i}} \mathrm{t}+\alpha_{\mathrm{i}}+\varepsilon_{\mathrm{i}} \mathrm{t}$

Model 4

AX4 $=\beta 0+\beta 1$ ROE $_{i} t+\beta 2$ FLINDEX $_{i} t+\beta 3$ FIRMAGE $_{\mathrm{i}}+\beta 4$ FIRMSIZE $_{\mathrm{i}}+$ $\beta 5$ GROWTHR $_{\mathrm{i}} \mathrm{t}+\beta 6$ TYINDSTRY $_{\mathrm{i}} \mathrm{t}+\alpha_{\mathrm{i}}+\varepsilon_{\mathrm{i}} \mathrm{t}$

Model 5

AX5 $=\beta 0+\beta 1$ SFATO $_{i} t+\beta 2$ ROA $_{i} t+\beta 3$ FIRMAGE $_{i} t+\beta 4$ FIRMSIZE $_{i} t+\beta 5$ GROWTHR $_{i} t$ $+\beta 6$ TYINDSTRY $Y_{\mathrm{i}} \mathrm{t}+\alpha_{\mathrm{i}}+\mathcal{E}_{\mathrm{i}} \mathrm{t}$

Model 6

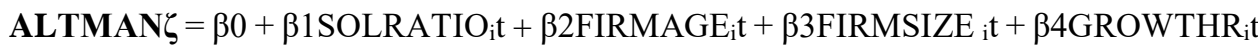
$+\beta 5$ TYINDSTRY $Y_{\mathrm{i}} \mathrm{t}+\alpha_{\mathrm{i}}+\varepsilon_{\mathrm{i}} \mathrm{t}$

where:

$\mathrm{i}=$ firm;

$\mathrm{t}=$ year;

$\alpha_{\mathrm{i}}=$ is the intercept for each sample (n entity-specific intercepts);

$\mathrm{Y}_{\mathrm{i}} \mathrm{t}=\mathrm{AX} 1-\mathrm{AX} 5$ \& ALTMAN $\zeta$ dependent variable, where $\mathrm{i}=$ firm and $\mathrm{t}=$ time;

$\mathrm{X}_{\mathrm{i}} \mathrm{t}=$ independent variable where $\mathrm{i}=$ firm and $\mathrm{t}=$ time;

$\beta 1=$ is the coefficient for independent variable; and

$\varepsilon_{\mathrm{i}} \mathrm{t}=$ is the error term. 
Table 1: Matching of Dependent Variables with Independent Variables

\begin{tabular}{|c|c|c|c|}
\hline Dependent Variables & VAR & Independent Variables & VAR \\
\hline Liquidity & $\mathrm{AX}_{1}$ & Liquidity Ratio & LIQRATIO \\
\hline $\begin{array}{l}\text { Financial Reliance \& Self } \\
\text { financing }\end{array}$ & $\mathrm{AX}_{2}$ & $\begin{array}{l}\text { Times Interest and Taxes } \\
\text { Earned }\end{array}$ & TINTTAXE \\
\hline \multirow{3}{*}{ Profitability } & \multirow{3}{*}{$\mathrm{AX}_{3}$} & Operating Profit Margin & $\mathrm{OPM}$ \\
\hline & & Return on Revenue & ROR \\
\hline & & Return On Investment & ROI \\
\hline \multirow{2}{*}{ Market Capitalisation } & \multirow{2}{*}{$\mathrm{AX}_{4}$} & Return On Equity & $\mathrm{ROE}$ \\
\hline & & Financial Leverage Index & FLINDEX \\
\hline \multirow{2}{*}{ Management Efficiency } & \multirow{2}{*}{$\mathrm{AX}_{5}$} & Fixed Assets Turn Over & FATO \\
\hline & & Return On Assets & $\mathrm{ROA}$ \\
\hline Bankruptcy Z-Score & ALTMAN $\zeta$ & Solvency Ratio & SOLRATIO \\
\hline
\end{tabular}

Table 2: Variable Descriptions and Sources

\begin{tabular}{|c|c|c|c|}
\hline \multicolumn{2}{|c|}{ Variables } & VAR & Description \\
\hline \multirow{6}{*}{$\begin{array}{l}\text { Dependent } \\
\text { Variables }\end{array}$} & Liquidity & $\mathrm{AX}_{1}$ & Ratio of Working Capital to Total Assets* \\
\hline & $\begin{array}{l}\text { Financial Reliance } \\
\text { \& Self-financing }\end{array}$ & $\mathrm{AX}_{2}$ & Ratio of Retained Earnings to Total Asset* \\
\hline & Profitability & $\mathrm{AX}_{3}$ & $\begin{array}{l}\text { Ratio of Earnings Before Interest and Taxes } \\
\text { to Total Assets* }\end{array}$ \\
\hline & $\begin{array}{l}\text { Market } \\
\text { Capitalisation }\end{array}$ & $\mathrm{AX}_{4}$ & Ratio of Net Worth to Total Liabilities* \\
\hline & $\begin{array}{l}\text { Management } \\
\text { Efficiency }\end{array}$ & $\mathrm{AX}_{5}$ & Ratio of Sales to Total Assets* \\
\hline & $\begin{array}{l}\text { Bankruptcy } \\
\text { Z-Score }\end{array}$ & ALTMAN $\zeta$ & $\begin{array}{l}\text { Summation of the products of AX1 to AX5 } \\
\text { multiplied by the corresponding Altman } \\
\text { constants. }\end{array}$ \\
\hline \multirow{8}{*}{$\begin{array}{l}\text { Independent } \\
\text { Variables }\end{array}$} & Solvency Ratio & SOLRATIO & Ratio of Total Debt to Total Asset* \\
\hline & Liquidity Ratio & LIQRATIO & $\begin{array}{l}\text { Ratio of Current Assets to Current } \\
\text { Liabilities* }\end{array}$ \\
\hline & $\begin{array}{l}\text { Fixed Assets Turn } \\
\text { Over }\end{array}$ & FATO & Ratio of Revenue to Total Assets* \\
\hline & $\begin{array}{l}\text { Times Interest and } \\
\text { Taxes Earned }\end{array}$ & TINTTAXE & $\begin{array}{l}\text { Ratio of Earnings before Interest and } \\
\text { Taxes to the sum of Interest and Taxes* }\end{array}$ \\
\hline & $\begin{array}{l}\text { Operating Profit } \\
\text { Margin }\end{array}$ & OPM & $\begin{array}{l}\text { Ratio of Earnings before Interest and Tax } \\
\text { to Revenue* }\end{array}$ \\
\hline & $\begin{array}{l}\text { Return on } \\
\text { Revenue } \\
\end{array}$ & ROR & Ratio of Net Income to Revenue* \\
\hline & Return On Assets & ROA & Ratio of Net Income to Total Assets* \\
\hline & $\begin{array}{l}\text { Return On } \\
\text { Investment }\end{array}$ & ROI & $\begin{array}{l}\text { Product of Return On Revenue and Asset } \\
\text { Turn Over* }\end{array}$ \\
\hline
\end{tabular}




\begin{tabular}{l|l|c|l}
\hline & Return On Equity & ROE & Ratio of Net Income to Net Worth* \\
\cline { 2 - 5 } & $\begin{array}{l}\text { Financial Leverage } \\
\text { Index }\end{array}$ & FLINDEX & $\begin{array}{l}\text { Ratio of Return On Equity to Return On } \\
\text { Assets* }\end{array}$ \\
\hline \multirow{2}{*}{$\begin{array}{l}\text { Control } \\
\text { Variables }\end{array}$} & Firm Age & FIRMAGE & $\begin{array}{l}\text { The actual age of the firms from the time of } \\
\text { incorporation to current year* }\end{array}$ \\
\cline { 2 - 5 } & Growth & FIRMSIZE & $\begin{array}{l}\text { The Capital Stock of each Publicly listed } \\
\text { Company* }\end{array}$ \\
\cline { 2 - 5 } & Type of Industry & TYINDSTRY & $\begin{array}{l}\text { The classification of company per } \\
\text { economic sector by Securities and } \\
\text { Exchange Commission }\end{array}$ \\
\hline
\end{tabular}

\section{Sources:}

*PSE EDGE - Processed and Analysed by Researcher ** PSE EDGE \& CAR - Given

\section{Results and Discussion}

\section{Age of publicly listed companies}

In this section, Table 3 presents that most of the publicly listed companies in the Philippines operate businesses at the range of age, 20-29 years, which accounts for nearly $26 \%$ of the companies in study. The older companies are limited, which compose only $7 \%$ of the companies and have operated at 120-129 years. This result is consistent with Ferrer and Banderlipe II (2012)'s descriptive statistics findings on the impact of corporate board features on business performance.

Table 3: Publicly Listed Company's Age

\begin{tabular}{ccc}
\hline \multicolumn{3}{c}{ Age of Publicly Listed Companies } \\
\hline Range & Frequency & Percentage \\
\hline $0-9$ & 5 & 3.68 \\
$10-19$ & 15 & 11.03 \\
$20-29$ & 35 & 25.74 \\
$30-39$ & 28 & 20.59 \\
$40-49$ & 18 & 13.24 \\
$50-59$ & 10 & 7.35 \\
$60-69$ & 12 & 8.82 \\
$70-79$ & 3 & 2.21 \\
$80-89$ & 4 & 2.94 \\
$90-99$ & 3 & 2.21 \\
$100-109$ & 2 & 1.47 \\
$120-129$ & 1 & 0.74 \\
\hline
\end{tabular}




\section{Size of publicly listed companies}

The capital stock of publicly traded companies was used to determine their size.

Table 4: Publicly Listed Company's Size

\begin{tabular}{ccc}
\hline \multicolumn{3}{c}{ Size of Publicly Listed Companies } \\
\hline Range & Frequency & Percentage \\
\hline $1-9,999,999,999$ & 129 & 94.16 \\
$10,000,000,000-10,999,999,999$ & 2 & 1.46 \\
$20,000,000,000-20,999,999,999$ & 2 & 1.46 \\
$30,000,000,000-30,999,999,999$ & 1 & 0.73 \\
$40,000,000,000-50,999,999,999$ & 1 & 0.73 \\
$110,000,000,000-120,999,999,999$ & 1 & 0.73 \\
\hline
\end{tabular}

Table 4 reveals that 129 firms, or 94.16 percent of all firms, have capital stock in the range of $1-9,999,999,999$, while just three firms have capital stock in the range of $30,000,000,000$ to P120,999,999,999. This result is comparable to McReynald's (2013) study, which looked at the effects of board qualities on the share prices of publicly traded holding companies.

\section{Growth of publicly listed companies}

To evaluate growth, each company's net profit margin was measured. A higher margin means that a company is more efficient in converting sales into actual profit. In range of negatives, it is presented that 3 companies are belonging to -31 to -40 , while the other ranges have one company each. This indicates that these companies do not have efficient cost control. On the other hand, there were 35 companies having the lowest positive growth bracket of 0-9 percent and there were 17 companies which reached the highest growth bracket of 100 percent and above. The gearing capacity of companies is determined to be favourable in 680 observations in the study. This argument is supported by ADBI's (2019) research, which evaluated 73 publicly traded firms in the Philippines. 
Table 5: Publicly Listed Company's Growth

\begin{tabular}{ccc}
\hline \multicolumn{3}{c}{ Growth of Publicly Listed Companies } \\
\hline Range & Frequency & Percentage \\
\hline$-41 \%$ and above & 1 & 0.74 \\
-40 to -31 & 3 & 2.21 \\
-30 to -21 & 2 & 1.47 \\
-20 to -11 & 1 & 0.74 \\
-10 to -1 & 1 & 0.74 \\
$0-9$ & 35 & 25.74 \\
$10-19$ & 33 & 24.26 \\
$20-29$ & 23 & 16.91 \\
$30-39$ & 10 & 7.35 \\
$40-49$ & 5 & 3.68 \\
$50-59$ & 1 & 0.74 \\
$60-69$ & 4 & 2.94 \\
$70-79$ & 2 & 1.47 \\
$80-89$ & 1 & 0.74 \\
$90-100$ & 2 & 1.47 \\
$110-119$ & 17 & 13.24 \\
\hline
\end{tabular}

Economic sectors of publicly listed companies

Table 6: Types of Company's Industry

\begin{tabular}{lcc}
\hline \multicolumn{1}{c}{ Type of Industry } \\
\hline Profile & Frequency & Percentage \\
\hline Propices & 27 & 19.85 \\
Holding firms & 21 & 15.44 \\
Mining & 22 & 16.18 \\
Mining and oil & 3 & 2.21 \\
Financials & 6 & 4.41 \\
Industrial & 13 & 9.55 \\
Small medium and emerging board & 43 & 31.62 \\
\hline
\end{tabular}

There are a total of 136 companies that were divided into eight (8) industries or economic sectors. The following public listed companies are classified as follows: (1) Industrial (2) Services (3) Holding Firms (4) Property (5) Financials (6) Mining and Oil (7) Mining (8) Small Medium and Emerging Board (SMEB). According to 
the data gathered, Industrial is the most common industry among the subject companies (31.62 percent) and the least is the SMEB. This result can be validated in the Philippine Stock Exchange open data repository (2013-2017).

\section{Examination of Solvency}

Solvency assessment helps business owners determine the chances of the firm's long-term survival.

Table 7: Degree of Company's Solvency

\begin{tabular}{lccc}
\hline \multicolumn{4}{c}{ Degree of Solvency } \\
\hline Industry & Solvent & Insolvent & Total \\
\hline A. Industrial & 40 & 3 & 43 \\
B. Services & 26 & 1 & 27 \\
C. Holding Firms & 21 & 0 & 21 \\
D. Property & 21 & 0 & 21 \\
E. Financials & 12 & 1 & 13 \\
F. Mining and Oil & 6 & 0 & 6 \\
G. Mining & 4 & 0 & 4 \\
H. Small medium and emerging board & 1 & 0 & 1
\end{tabular}

Legend: (Above 20\% - solvent, Below 20\% - Insolvent)

Table 7 presents the solvency assessment of the publicly listed companies. Most publicly-listed companies in the Philippines are solvent before CoVid-19 outbreak. The outcomes of the solvency evaluation are consistent with the findings of Lizares and Bautista (2021) in evaluating financial distress of publicly traded corporations in emerging markets. Based on the descriptive statistics of Altman Z-scores, majority of publicly listed companies in the Philippines have liquidity level, and financial reliance \& self-financing indicators that are ideal. They also have profitability ratios and market capitalisation variables that are above the threshold of favourable outcomes per financial analyses. Regarding management efficiency metric, the results indicate efficiency of most companies. Thus, the Altman Z-score indicates few companies that are suffering from financial distress. The thresholds and measures were based on Aduana (2015), Helfert (2015) and Wang and Zhou (2016). 
Evaluation of Financial Distress through Altman Z-scores

Table 8: Altman Z-score of Publicly Listed Companies

\begin{tabular}{lcccc}
\hline \multicolumn{1}{c}{ Industry } & $\begin{array}{c}\text { Altman Z-Score } \\
\text { Zone } \\
\text { of Distress }\end{array}$ & Grey Zone & $\begin{array}{c}\text { Zone } \\
\text { of Stability }\end{array}$ & Total \\
\hline Financials & 7 & 8 & 11 & 26 \\
Holding firms & 13 & 7 & 1 & 21 \\
Industrial & 3 & 8 & 11 & 22 \\
Mining & 3 & 1 & - & 4 \\
Mining and oil & - & 2 & 4 & 6 \\
Property & 9 & 1 & 0 & 10 \\
Services & 12 & 12 & 14 & 38 \\
Small medium and emerging board & 1 & - & - & 1 \\
Totals & 48 & 39 & 41 & 128 \\
Legend: (Less than 1.20 High chances of bankruptcy, Between 1.20 and 2.90 - Gray or ambiguous, \\
More than 2.90 - Low or no chances of bankruptcy) & & & \\
\hline
\end{tabular}

Most of the companies which are at a high risk of bankruptcy were under the Property sector. The Industrial sector had the most companies under gray or ambiguous risk level with 12 companies, and it also had the most companies with low or no chance of bankruptcy at 14 companies. The findings are consistent with Mahama's (2015) analysis, which found six companies in Ghana to be financially sound and not in danger of financial hardship. The review also agrees with Lim (1998), who stated in his article that corporate distress existed in the Philippines in 1998, and that intervention and appropriate corporate management should be carried out profitably.

Table 9: Altman Z-score of Publicly Listed Companies in Relation to the Total Observations

\begin{tabular}{lcccc}
\hline \multicolumn{4}{c}{ Altman Z-Score through the General Altman Model $\zeta$} \\
Industry & $\begin{array}{c}\text { Zone } \\
\text { of } \\
\text { Stability }\end{array}$ & Grey Zone & $\begin{array}{c}\text { Zone } \\
\text { of } \\
\text { Distress }\end{array}$ & Total \\
\hline Financials & 17 & 2 & 46 & 65 \\
Holding firms & 43 & 26 & 41 & 110 \\
Industrial & 82 & 44 & 84 & 210 \\
Mining & 2 & 1 & 17 & 20 \\
Mining and oil & 19 & 7 & 4 & 30 \\
Property & 19 & 19 & 67 & 105 \\
Services & 59 & 23 & 53 & 135 \\
Small medium and emerging board & 0 & 1 & 4 & 5
\end{tabular}


Totals

Legend: (Less than 1.80 High chances of bankruptcy, Between 1.80 and 3.00 - Gray or ambiguous, More than 3.00 - Low or no chances of bankruptcy)

Altman Z-Score through the Altman Model for Manufacturers and Publicly Listed Companies $\zeta$

\begin{tabular}{lcccc}
\multicolumn{1}{c}{ Industry } & $\begin{array}{c}\text { Zone } \\
\text { of } \\
\text { Stability }\end{array}$ & Grey Zone & $\begin{array}{c}\text { Zone } \\
\text { of } \\
\text { Distress }\end{array}$ & Total \\
\hline Financials & 15 & 4 & 46 & 65 \\
Holding firms & 37 & 37 & 36 & 110 \\
Industrial & 65 & 79 & 66 & 210 \\
Mining & 1 & 2 & 17 & 20 \\
Mining and oil & 17 & 11 & 2 & 30 \\
Property & 15 & 27 & 63 & 105 \\
Services & 48 & 43 & 44 & 135 \\
Small medium and emerging board & 0 & 1 & 4 & 5 \\
Totals & 198 & 204 & 278 & 680
\end{tabular}

Legend: (Less than 1.20 High chances of bankruptcy, Between 1.20 and 2.90 - Gray or ambiguous, More than 2.90 - Low or no chances of bankruptcy )

Table 9 shows the evaluation of financial distress on 680 observations or year entries. Based on the general Altman Z-score Model, the Mining sector, followed by Small medium and emerging board and financial sector has the greatest number of distressed companies by annual performance from 2013 to 2017. The mining and oil sector, followed by Services has the highest degree of stability. While most firms in Holding Companies sector are in grey zone. The Altman model for Manufacturers and Publicly Listed Companies generates the same results for stability and distress. The only difference lies with the zone of ambiguity wherein most firms in Industrial sector are found to be in the grey zone per Altman Z-score model for publicly listed companies. The findings of the study through Altman Z-score evaluation corroborate Klapper, Claessens, and Djankov (1999), Claessens, Djankov, and Klapper (2003), Tuvadaratragool (2013), and Gao, Parsons, and Shen's studies (2018).

\section{Untying the Empirical Knots of Deterioration of Profitability, Economic Failure and Financial Insolvency}

The results of panel regression reveal no significant associations between variables involved. Return On Revenue for Profitability and Return On Assets for Management Efficiency are the only variables with p-values lower than the alpha- 
level of 0.05 , with positive coefficients of 2.92 percent and 56.92 percent, respectively. Because the results of solvency evaluation and financial distress analysis show that the majority of publicly traded firms in the Philippines are in the Zone of Stability and Ambiguity, no significant ties have been found with the majority of variables involved. As a result, the majority of accounting indicators expressed in financial position and performance ratios are favourable and viable, and do not indicate a significant decline in profitability, economic failure, or financial insolvency. Deterioration of profitability as measured by times interest and taxes earned, operational profit margin, fixed asset turnover, and asset turnover. Based on econometric and accounting analysis, 77.94 percent of the 680 observations are profitable, 6.62 percent are highly profitable, and only 15.44 percent have deteriorating profitability.

Based on Operating Profit Margin, 84.71 percent of 680 observations are profitable, 4.12 percent are highly profitable, and just 11.18 percent have deteriorating profitability. Fixed Assets Turnover is profitable to extremely profitable in $34.85 \%$ of cases, whereas fixed asset utilisation is inefficient in 65.15 percent of cases. In terms of asset turnover, 94.71 percent are effectively using their assets, 3.97 percent are highly profitable, and 1.32 percent are experiencing declining profitability. As a result, no significant deterioration in profitability has been noticed. The findings show that there are no significant connections or ties between the Altman Z-scores of financial reliance and self-financing capacity, profitability, and management efficiency since profitability is not deteriorating.

Table 10: Results of Panel Regression on Financial Distress - Individual Components

\begin{tabular}{lcccc}
\hline Dependent Variable & \multicolumn{3}{c}{ Financial Distress and Bankruptcy } \\
\hline Independent Variables & Coef. & Std. Err. & T-Stat & P Value \\
\hline Liquidity Ratio & 0.0087 & 0.0229 & 0.3800 & 0.7050 \\
ALTMANX1 & 0.2754 & 0.1199 & 2.3000 & 0.0220 \\
Age & $-4.05 \mathrm{E}-11$ & $1.63 \mathrm{E}-10$ & -0.2500 & 0.8040 \\
Size & -0.0000 & 0.0002 & -0.1100 & 0.9120 \\
Growth & -0.1033 & 0.9066 & -0.1100 & 0.9090 \\
Economic Sector & -0.6454 & 7.9179 & -0.0800 & 0.9350 \\
cons & & & & \\
& & & & P-Stat \\
Financial Reliance E Self- & Coef. & Std. Err. & -0.0900 & 0.9250 \\
financing & -0.0004 & 0.0044 & -1.0700 & 0.2830 \\
ALTMANX2 & -0.1517 & 0.1413 & -0.0900 & 0.9300 \\
Age & $-2.00 \mathrm{E}-11$ & $2.28 \mathrm{E}-10$ & -0.1500 & 0.8780 \\
Size & -0.0000 & 0.0002 & & \\
Growth & & & & \\
\hline
\end{tabular}




\begin{tabular}{lcccc}
\hline Economic Sector & -1.3787 & 1.0670 & -1.2900 & 0.1960 \\
_cons & 19.0419 & 9.3663 & 2.0300 & 0.0420 \\
& & & & \\
Profitability & Coef. & Std. Err. & T-Stat & P Value \\
Return On Revenue & 0.02925 & 0.0036 & 8.1100 & 0.0000 \\
Operating Profit Margin & -0.0309 & 0.01513 & -2.0400 & 0.0410 \\
ALTMANX3 & 0.0006 & 0.0007 & 0.8600 & 0.3920 \\
Age & 0.0019 & 0.0360 & 0.0500 & 0.9570 \\
Size & $1.51 \mathrm{E}-11$ & $4.71 \mathrm{E}-11$ & 0.3200 & 0.7480 \\
Economic Sector & 0.1235 & 0.2725 & 0.4500 & 0.6500 \\
_cons & 0.2835 & 2.3708 & 0.1200 & 0.9050 \\
& & & & \\
Market Capitalisation & Coef. & Std. Err. & T-Stat & P Value \\
Financial Leverage Index & 0.4595 & 0.5623 & 0.8200 & 0.4140 \\
ALTMANX4 & -0.0312 & 0.0252 & -1.2300 & 0.2170 \\
Age & -0.0256 & 0.0932 & -0.2800 & 0.7830 \\
Size & $7.59 \mathrm{E}-12$ & $1.24 \mathrm{E}-10$ & 0.0600 & 0.9510 \\
Growth & 0.0008 & 0.0001 & 7.6900 & 0.0000 \\
Economic Sector & 0.2523 & 0.7094 & 0.3600 & 0.7220 \\
_cons & 2.2292 & 6.3794 & 0.3500 & 0.7270 \\
& & & & \\
Management Efficiency & Coef. & Std. Err. & T-Stat & P Value \\
Return On Assets & 0.5692 & 0.0636 & 8.9500 & 0.0000 \\
ALTMANX5 & -0.0002 & 0.0006 & -0.300 & 0.7640 \\
Age & -0.1229 & 0.0705 & -1.7400 & 0.0810 \\
Size & $9.58 \mathrm{E}-12$ & $8.89 \mathrm{E}-11$ & 0.1100 & 0.9140 \\
Growth & -0.0002 & 0.0000 & -2.6500 & 0.0080 \\
Economic Sector & 0.2613 & 0.54014 & 0.4800 & 0.6290 \\
_cons & 6.8253 & 4.7148 & 1.4500 & 0.1480 \\
\hline
\end{tabular}

Hence, the empirical knots of deterioration of profitability to financial distress have been untied. When the knots of return on revenue, assets, investment, and equity were evaluated in relation to financial distress, the results proved that no economic failure exists. According to the net profit margin, 63.82 percent earn profits ranging from 5 to 200 percent of total revenues, with 7.65 percent generating returns surpassing 200 percent of annual sales. Only 28.53 percent are losing money, indicating that the economy is failing. In terms of return on assets, 4.41 percent of firms earn profits of more than 100 percent, while 34.85 percent generate profits ranging from 5 to 100 percent of total assets used by companies. There is less evidence of economic failure per return on asset analysis. Moreover, based on return on investment and equity analyses, it is apparent that 34.85 percent and 56.03 percent are generating returns of 5 percent to 100 percent of investment and equity, and 3.82 percent and 6.32 percent are deriving profits from investments and equity, that are more than the value of investments and equity. As a result, no economic failure was found in the study's 680 observations. 
With the foregoing, it is reasonable to conclude that profitability has not deteriorated. As a result, there is no economic failure in the case of publicly listed firms in the Philippines.

The knots of insolvency and financial distress have been untangled. According to the liquidity test, 64.71 percent of the 680 observations are liquid, and 14.26 percent are very liquid, with current assets equal to or greater than the amount of currently maturing obligations. Insolvent observations account for only 21.03 percent of all observations. In terms of financial leverage, 58.82 percent have an optimal financial leverage index, 33.82 percent have practical leverage, and only 7.35 percent have insolvency owing to excessive debt financing. In reference to Table 5, the findings of the solvency evaluation, which demonstrated that 96 percent of the 680 observations are solvent. Thus, financial insolvency is not present in the Philippine context from 2013 to 2017. Hence, there is no significant ties between the liquidity, market capitalisation, and the Altman Zscore to financial insolvency indicators because financial distress is not prevalent.

With a p-value of 0.896 , which is higher than the 0.05 significance level, Table 9 shows that solvency has no meaningful association to financial distress. The p-Value (0.896 and 0.851) of the variable indicates a weak degree of significance. As a result, it is apparent that the solvency ratio cannot evaluate the likelihood of bankruptcy in the Philippine context.

Table 11: Results of Panel Regression on Financial Distress - General Business, and Manufacturing and PLCs

\begin{tabular}{lcccc}
\hline \multicolumn{1}{c}{ Dependent Variable } & \multicolumn{3}{c}{ Financial Distress $-\begin{array}{c}\text { General Business, and Manufacturing } \\
\text { and PLCs }\end{array}$} \\
\hline Independent Variables & Coef. & Std. Err. & T-Stat & P Value \\
\hline Solvency & 0.0002 & 0.0009 & 0.1900 & 0.8510 \\
ALTMANGEN & 0.0162 & 0.1500 & 0.1100 & 0.9140 \\
Age & $-1.45 \mathrm{E}-10$ & $1.99 \mathrm{E}-10$ & -0.7300 & 0.4670 \\
Size & 0.0000 & 0.0001 & 0.2700 & 0.7850 \\
Growth & 0.0171 & 1.1345 & 0.0200 & 0.9880 \\
Economic Sector & 13.1978 & 9.8852 & 1.3400 & 0.1820 \\
_cons & & & & \\
& 0.0001 & 0.0010 & 0.1300 & 0.8960 \\
ALTMANPLCS & 0.0161 & 0.15005 & 0.1100 & 0.9150 \\
Age & $-1.45 \mathrm{E}-10$ & $1.99 \mathrm{E}-10$ & -0.7300 & 0.4670 \\
Size & 0.0000 & 0.0002 & 0.2700 & 0.7850 \\
Growth & 0.0158 & 1.1345 & 0.0100 & 0.9890 \\
Economic Sector & 13.2157 & 9.8850 & 1.3400 & 0.1810 \\
_cons & & &
\end{tabular}


Financial distress as evaluated by the two models of Altman Z-scores has no significant relationship with the solvency ratio as evaluated by accounting indicators of liabilities and assets. The majority of publicly-traded companies in the Philippines did not have material evidence of declining profitability, economic collapse, or financial insolvency between 2013 and 2017. The study's overall findings support Altman's (1968), Ohlson's (1980), and Brîndescu-Olariu's (2015) assertions and claims. The Altman Z-score is a reliable indicator of a firm's stability and likelihood of bankruptcy. The study's conclusions, however, differ from the context of Brîndescu-Olariu (2016a).

\section{Conclusions and Recommendations}

Because most businesses are solvent, the findings suggest that solvency is not strongly linked to financial difficulty. In terms of its effects, it was concluded that solvency has little bearing on anticipating financial distress in the Philippines. Companies with a high solvency ratio demonstrate greater assurances in the event of forced liquidation, which can lower lenders' perceived risks and the pressure to file for bankruptcy. However, in the Philippines, a number of factors, including external and internal management issues, may influence bankruptcy. As a result, the solvency ratio for publicly traded companies in the Philippines is not an useful predictor of bankruptcy. Other control variables utilised in the study, have less relation to financial distress. Their coefficients had no bearing on the likelihood of a company's financial distress. It has also been determined that the majority of publicly traded companies in the Philippines are in a zone of stability and uncertainty, and hence the country's financial distress from 2013 to 2017 is less visible. Business profitability is not declining with the foregoing, economic failure is less evident, and financial insolvency is not pervasive. As a result, there is no evidence of financial distress among publicly traded companies in general. The aforementioned knots were loosened, demonstrating that the knots are flimsy as at the evaluation phase.

Financial and operations managers in wealth-maximising firms should not rely solely on the solvency ratio to diagnose their financial distress. Companies will be able to examine financial distress by taking into account a variety of elements. Management accountants could make Cross-sectional financial analysis of accounting data and econometrics models should be devised to validate the results of accounting information. The outcomes of analyses are meant to provide direction for accountants, professionals, and freelancers by advising investors and clients on how to invest their assets or cash. It will undoubtedly aid them in deciding which companies are likely to offer favourable 
returns, appropriate yields, and optimal investment opportunities and interests. Based on the Altman Z-score study, the results may assist investors in identifying companies that may have financial difficulties in the future. By favouring companies that are within the zone of stability, investors can reduce the risks associated with their investments. This research would prove to creditors that the company they are about to lend or extend a loan to will repay the debt or has a sound financial position, as evidenced by the growth and profitability analysis. The results of this study can be valuable to academic and business research undertakings. When accounting data on financial performance and position are made available by the Philippine Stock Exchange, the researcher will be conducting a similar study for 2018 to 2022, amidst CoVid-19 outbreak.

\section{Acknowledgements}

The researcher wishes to express his heartfelt gratitude to Professor Renz Adrian Calub, Dr. Allelie Sobrevinas, Dr. Dickson Lim, and Dean Marites Tiongco of the School of Economics, De La Salle University for delightful inputs in econometrics. The same appreciation is extended to Professor Rolan Jon G. Bulao, Professor Calyd T. Cerio, Professor Ariel N. Delfino, and Dean Rina A. Abner of the College of Business in Management to share significant financial insights analyses. He would also want to extend his commendation to his younger brothers, Marvin and Marc, for their politeness, throughout the study. To God be the glory!

\section{References}

ADBI. (2019). Corporate Governance, Firm Profitability, and Share Valuation in the Philippines. Creative Commons Attribution 3.0 IGO license (CC BY 3.0 IGO). Retrieved from https://www.adb.org/sites/default/files/publication/549336/corporategovernance-firm-profitabilty-philippines.pdf

Aziz, M. A., \& Dar, H. A. (2006). Predicting corporate bankruptcy: where we stand?. Corporate Governance: The international journal of business in society.

Aduana, N. L. (2015). Financial Statements Preparation, Presentation, Analysis, and Interpretation. Quezon City: C \& E Publishing, Inc. Retrieved from https://www.carousell.ph/p/financial-statements-preparationpresentation-analysis-and-interpretation-by-nick-aduana-177301151/ 
Altman, E. I. (1968). Financial Ratios, Discriminant Analysis and the Prediction of Corporate Bankruptcy. The Journal of Finance, 23(4), 589-609. https://www.jstor.org/stable/2978933

Brîndescu-Olariu, D. (2014). The potential of the equity working capital in the prediction of bankruptcy. Management intercultural, (31), 25-32.

Brîndescu-Olariu, D. (2015). The Potential of the Debt ratio in the Prediction of Corporate Bankruptcy. Journal of Public Administration, Finance and Law, (special), 37-45.

Brîndescu-Olariu, D. (2016a). Solvency Ratio as a Tool for Bankruptcy Prediction. Paper submitted for publication. Retrieved from http://ecoforumjournal.ro/index.php/eco/article/viewFile/418/265

Brîndescu-Olariu, D. (2016b). Bankruptcy Prediction Based on the Debt Ratio. Theoretical and Applied Economics, XXIII(2), 145-156. Retrieved from https://econpapers.repec.org/article/agrjournl/v_3axxiii_3ay_3a2016_3ai_3a 2(607)_3ap_3a145-156.htm

Brigham, E. F., \& Daves, P. R. (2007). Intermediate Financial Management. Mason: Thomson Higher Education. Retrieved from https://bandi.feb.uns.ac.id/wpcontent/uploads/2018/09/intermediate-brigham-full.pdf

Chung, K. C., Tan, S. S., \& Holdsworth, D. K. (2008). Insolvency Prediction Model Using Multivariate. International Journal of Business and Management.

Chouhan, V., Chandra, B., \& Goswami, S. (2014). Predicting Financial Stability of Select BSE Companies Revisiting Altman Z Score. International Letters of Social and Humanistic Sciences, 15(2), 92-105.

Claessens, S., Djankov, S., \& Klapper, L. (2003). Resolution of Corporate Distress in East Asia. Journal of Empirical Finance, 10(1-2), 199-216. Retrieved from https://www.researchgate.net/publication/222567155_Resolution_of_Corpo rate_Distress_in_East_Asia

Enyi, E. P. (2008). A Comparative Analysis of the Effectiveness of Three Solvency Management Models. Retrieved from https://papers.ssrn.com/sol3/papers.cfm?abstract_id=1138357

Ferrer, R. C., \& Banderlipe II, M. R. S. (2012). The Influence of Corporate Board Characteristics on Firm Performance of Publicly Listed Property Companies in the Philippines. Academy of Accounting \& Financial Studies Journal, 16(4), 123-142. Retrieved from https://www.researchgate.net/profile/Mcrey-Banderlipeli/publication/288095245_The_influence_of_corporate_board_characteristic s_on_firm_performance_of_publicly_listed_property_companies_in_the_phi lippines/links/56c4270c08aee3dcd416eaff/The-influence-of-corporateboard-characteristics-on-firm-performance-of-publicly-listed-propertycompanies-in-the-philippines.pdf 
Gao, P., Parsons, C. A., \& Shen, J. (2018). Global Relation Between Financial Distress and Equity Returns. The Review of Financial Studies, 31(1), 239-277. Retrieved from https://academic.oup.com/rfs/articleabstract/31/1/239/3867963

Greene, W. (2002). Econometrics Analysis. New York: Prentice Hall.

Helfert, E. (2015). Financial Analysis: Tools and Techniques - A Guide for Managers. New York: McGraw-Hill. Retrieved from https://www.academia.edu/2124620/Financial_analysis_tools_and_techniq ues_a_guide_for_managers

Klapper, L., Claessens, S., \& Djankov, S. (1999). Resolution of Corporate Distress: Evidence from East Asia's Financial Crisis. Washington, DC: World Bank. Retrieved from https://elibrary.worldbank.org/doi/abs/10.1596/1813-94502133

Lim, C. H. (1998). Managing Corporate Distress in the Philippines: Some Policy Recommendations. IMF Working Paper No. 98/138. Retrieved from https://papers.ssrn.com/sol3/papers.cfm?abstract_id=882700

Lizares, R. M., \& Bautista, C. C. (2021). Corporate Financial Distress: The Case of Publicly Listed Firms in an Emerging Market Economy. Journal of International Financial Management $\mathcal{E}$ Accounting, 32(1), 5-20. Retrieved from https://onlinelibrary.wiley.com/doi/abs/10.1111/jifm.12122

Mahama, M. (2015). Assessing the State of Financial Distress in Listed Companies in Ghana: Signs, Sources, Detection and Elimination-A Test of Altman's ZScore. European Journal of Business and Management, 7(3), 1-10. Retrieved from

https://citeseerx.ist.psu.edu/viewdoc/download?doi=10.1.1.679.5915\&rep=r ep1\&type=pdf

McReynald, S. (2013). Board Characteristics and Its Impact on Share Prices of Publicly Listed Holding Companies in the Philippines. Retrieved from https://www.researchgate.net/profile/Mcrey-Banderlipe-

li/publication/294814145_Board_Characteristics_and_its_Impact_on_Share_ Prices_of_Publicly-

Listed_Holding_Companies_in_the_Philippines/links/56c426af08ae60234251

249b/Board-Characteristics-and-its-Impact-on-Share-Prices-of-Publicly-

Listed-Holding-Companies-in-the-Philippines.pdf

Outecheva, N. (2007). Corporate Financial Distress: An Empirical Analysis of Distress Risk (Doctoral thesis), Graduate School of Business Administration, Economics, Law and Social Sciences, University of St. Gallen, St. Gallen, Switzerland. Retrieved from https://www.ehelvetica.nb.admin.ch/api/download/urn\%3Anbn\%3Ach\%3Abel130003\%3Adis3430.pdf 
Ohlson, J. A. (1980). Financial Ratios and the Probabilistic Prediction of Bankruptcy. Journal of Accounting Research, 18, 109-131. Retrieved from https://www.jstor.org/stable/2490395

Pauli, J., \& Wolf, M. (2017). Hanjin Shipping: Slow-Steaming into Bankruptcy: Causes and Effects (Master's thesis), School of Business, Economics and Law, University of Gothenburg, Gothenburg, Sweden. Retrieved from https://gupea.ub.gu.se/handle/2077/52799

Russ, R. W., Peffley, W. W., \& Greenfield, A. C. (2004, January 6). The Altman ZScore Revisited. Retrieved from https://papers.ssrn.com/sol3/papers.cfm?abstract_id $=484923$

Torres-Reyna, O. (2007). Panel Data Analysis - Fixed and Random Effects using Stata (v. 4.2). Princeton: Data and Statistical Services, Priceton University.

Tuvadaratragool, S. (2013). The Role of Financial Ratios in Signalling Financial Distress: Evidence from Thai Listed Companies (Doctoral dissertation), Southern Cross University, East Lismore, Australia. Retrieved from https://researchportal.scu.edu.au/esploro/outputs/doctoral/The-role-offinancial-ratios-in-signalling-financial-distress--evidence-from-Thai-listedcompanies/991012821520902368

Wang, D., \& Zhou, F. (2016). The Application of Financial Analysis in Business Management. Open Journal of Business and Management, 4, 471-475. Retrieved from https://www.scirp.org/journal/paperinformation .aspx? paperid $=68268$

Whitaker, R. (1999). The Early Stages of Financial Distress. Journal of Economics and Finance, 23(2), 12-132. Retrieved from https://link.springer.com/article/10.1007/BF02745946

Cite this paper (APA):

Onsay, E. (2021). Untying empirical knots: Deterioration of profitability, economic failure, and financial insolvency in the Philippines before CoVid-19 Outbreak. JATIJournal of Southeast Asian Studies, 26(1), 21-48

Date received: 8 June $2021 \quad$ Date of acceptance: 26 June 2021 